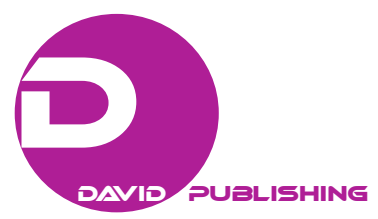

\title{
The Cult of Tian Hou in the Mekong Delta: The Formation and Characteristics*
}

\author{
Nguyen Ngoc Tho \\ Vietnam National University, Ho Chi Minh City, Vietnam
}

\begin{abstract}
Vietnam is the land of all original and absorbed goddesses in Southeast Asia. Local goddesses such as Lieu Hanh, Ba Chua Kho, Thien Yana Ponagar, Ba Den, Ba Chua Xu or external goddess such as Xi Wangmu (西王母), Kwan Yin (觀音), Yao Chi Jin Mu (瑤池金母), Tian Hou (天後), Mother Dragon Goddess (龍母娘娘), Jin Hua Goddess (金花夫人) etc. all are worshipped simultaneously throughout the nation. Among those, the cult of Tian Hou has become the most typical external goddess belief which absorbs both the cults of Kwan Yin and Xi Wang Mu, at the certain extend, become a symbol of harmonization. The cult of Tian Hou originated in Fujian, China and was gradually brought into South Vietnam after the footsteps of South Chinese immigrants during 17th-20th century. There are around 50 Tian Hou temples built and owned by the ethnic Hoa (華族/Chinese) and the Vietnamese at the Mekong River Delta. In the Mekong residents' mind, Tian Hou is seen as a maritime goddess, a protector, a benevolent Mother Goddess who has been accepted through the channels of Mahayana Buddhism and traditional goddess beliefs in the local communities. This paper is to investigate the current situation of the cult of Tian Hou in the Mekong River Delta to highlight the basic characteristics of this cult in the region.
\end{abstract}

Keywords: Tian Hou, the Mekong River Delta, identity, multi-cultural exchange

\section{The Cult of Tian Hou and the Propagation to Vietnam}

According to etymology, the term "belief (信仰)" contains both "trust/信” and "expectation/admiration (仰)”. Ngo Duc Thinh (2001) once discussed:

The belief is understood as human's trust and expectation towards something holy, noble, supernatural, or in summary it is the belief and admiration for "the holiness" that opposite to "the earthliness" that we can touch and observe etc. The belief itself is sorely the trust on "the holiness". (p. 16)

Therefore, the trust on "the holiness is always available in human's nature, it is present and influential to human life, thinking, and sentimental life...". Therefore, the common term "belief" can be understood generally as the value system of spiritual belief that human creates to represent good hopes as well as desires on supernatural powers to protect against disasters or fears which come from the natural world. The belief is originated from human's powerlessness in front of the natural world and its rules which are normally deified and worshipped as supernatural powers.

In East Asia, the belief has got large functions in most of the cultures. It penetrates deeply into spiritual

\footnotetext{
* This research is funded by Vietnam National Foundation for Science and Technology Development (NAFOSTED) under grant number IV5.2-2012.20.

Nguyen Ngoc Tho, Ph.D., University of Social Sciences and Humanities, Vietnam National University-Ho Chi Minh City.
} 
life, affects many aspects of social and moral lives such as custom, festival, cast lots, arts, ect. The traditional belief in this region has got few basic characteristics such as polytheism, hybridity, popularity of goddess rather than god, especially from South China to Southeast Asia (Nguyen, 2009).

The cult of Tian Hou (天後) was formed in Song dynasty at Meizhou, Putian, Fujian, China. Tian Hou, a famous magician, daughter of a fisherman, has got the real name Lin Mo (林默), often called as Lin Moniang (林默娘), born on March 23, 960 (Ma, S. T., Ma, S. X., 2006, pp. 8-10). The book Classic References in Qing Dynasty of China. Bodhisattva Local Chronicle (《中國大清會典事例。菩薩外傳》) as well as many local monographs ever wrote: Lin Mo was very intelligent, resourceful. She helped people to overcome misfortunes, taught them to adapt the civilized life and got rid of diseases. One day, she took a nap and saw her father and brother in a typhoon offshore, she used special power to rescue brother. While trying to save her father she was waken up by her mother, so she failed. After that she often used her sacred capacity to help people such as teaching fishermen to use seaweed as food aid, mat as sail, praying for rain, defeating two sprites Shun Feng Er and Li Tian Yan, abolishing flood/hurricane, curing people, placing talisman in well, ascending heaven in Mizhou island, ect. People believed that she was the daughter of the Jade Emperor of Heaven. She deceased on September 9, 987 at the age of 28; at first, Mizhou islanders built a temple to worship her, called Mazu Temple (媽祖廟). The legend said that she used to appear to help people on the sea; therefore, people praised her as sea goddess $^{1}$ (Zhu, 1990, p. 86; Li, 1995, pp.19-23; Luo, 2006, pp. 1-4).

By the year 1086, Nan Song dynasty advocated for this cult, King Song Xuan Hua (1119-1125) confered her the title "Ling Hui Fei” (靈惠妃), thence the cult's influence has been expanded day by day. To 1195, King Song Ning Zong continuously confered her the title "Heavenly Assistant (助天)" (Xu, 2007, p. 75), while people called her Heavenly Princess (圣妃). In early Yuan dynasty, she became "Tian Fei" (天妃, the year 15th of Yuan Shi Zu dynasty), from that day the cult of Tian Hou has been developed to the lower section of Yangtzi River Basin and Shandong peninsula. From Ming dynasty, due to the demand of marine trades with Southeast Asia, this cult was propagandized to Canton, Taiwan, and Southeast Asia. In Qing dynasty, Kang Xi Emporer period (1682), she was called Tian Hou Mother Goddess (天後聖母) (Li，1995；Xu，2007, pp. 199-201) $)^{2}$. The book Mazu Palace Collection (媽祖宮集成) wrote that more than 450 districts, towns and cities built Tian Hou temples in China. The Minnanese (South Fujianese) and the Hainanese prefer calling her the First Mother Goddess or Mazu (媽祖), the Cantonese call her Virtous Goddess or Tian Hou. In Ha Tien town and Ca Mau peninsula (Vietnam), the local people called her Ma Chau/Mazu Goddess ${ }^{3}$. In this paper we unify the title Tian Hou, because this belief was introduced into Vietnam relatively late, and most of the Vietnamese and ethnic Chinese officially call her Tian Hou.

The cult of Tian Hou in China has experienced more than 1,000 years, existed in the harmony with Daoism, Buddhism and compromised with Confucianism to create the face of South Chinese culture (Luo, 2006). However, this cult is naturally popular religion, bringing all closely and simply traditional characteristics of folk culture.

The Chinese have praised Mazu-Tian Hou, considered her as sea/water-nymph goddess, the protector and goddess of prosperousness, ect., sometimes she is identical with Kwan Yin in traditional Mahayana

\footnotetext{
${ }^{1}$ Wrote in Tian Hou Monograph, The Truth of Pious Girl with Surname Lin, 天妃顯聖錄, 夷堅誌.

${ }^{2}$ In the academic circle, there are some scholars still argued that the title “天啟後” confered in Ming dynasty, Thien Khai king (Xu, 2007, p. 200).

3 Such as Ma Chau/Mazu Goddess temple (雷瓊會館) in Ha Tien (Nguyen, 2014).
} 
Buddhism, with Heavenly Empress of the West (西王母) in Daoism, with Linshui goddess (林水夫人), Jinhua goddess (金花夫人) in local Mother Goddess beliefs in South China (Nguyen, 2011, p. 42-60). In Taiwan, some Holo families live in Pintung County worshipping Tian Hou and Kwan Kong in their houses (fieldwork 2013).

The cult of Tian Hou has been introduced into the South Vietnam by Chinese immigrants during in Ming -Qing dynasties, especially at the end of Ming and the beginning of Qing. The first stage around 1670s, there were nearly 7,000 South Chinese headed by Duong Ngan Dich/Yang Andi and Tran Thuong Xuyen/Chen Shangchuan (both the Cantonese), they settled down in Dong Nai, De Ngan (Cho Lon) and My Tho (Fujiwara, 1949, p. 379; Chen, 1960a, p. 436; Chen, 1960b; Xu \& Xie, 2000, p. 3; Mio, 2008, p. 5). Before that, a general of Leizhou named Mac Cuu/Mo Jiu has explored Ha Tien area, then developing gradually to Ca Mau peninsula in 1671 (Xu \& Xie, 2000, p. 5). From 17th century to early 20th century, increasing numbers of Chinese immigrants continuously migrated to South Vietnam. According to Tsai Maw Kuey (1968), the five-year period from 1925 to 1930 witnessed 237,000 Chinese to South Vietnam and 136,000 others left Vietnam for other countries (p. 52). From there, the Hoa has lived in harmony with native communities including the Vietnamese, the Khmer and the Cham, and contributed in building South Vietnamese culture. Nowadays, in South Vietnam there are around 800,000 Hoa people (2009) in which nearly 300,000 people live in the Mekong River Delta, divided into five groups Cantonese, Chaozhou, Fujian, Hainanese and Hakka. The Cantonese, pursuant to C. William Skinner (Tsai, 1968, p. 76) ${ }^{4}$, is the biggest group, mainly settling in Ho Chi Minh city and important towns/cities alongside of Mekong River; the Chaozhou resides mainly in Ca Mau peninsula (Soc Trang, Bac Lieu, Ca Mau) and Rach Gia-Ha Tien; the Fujianese scattered live along two banks of Mekong River and the area of Binh Duong, Dong Nai; the Hainanese live in some coastal towns and cities; the Hakka (He) lives in all places, especially in Buu Long mountain (Bien Hoa, Dong Nai) and Seven Mountains Region (An Giang). At first period, all five groups had built some Seven-Prefecture Ancient Temples (七府古廟) together (Bien Hoa, Ho Chi Minh city, My Tho, Vinh Long, ect), mainly praised Tian Hou, Kwan Kong, Ben Tougong (本頭功) but later each group separated and built temples for themselves with diversified forms to distinguish each other.

On sea way, they often prayed Tian Hou for her supports. When settling safely in Southern Vietnam, the immigrants built temples to worship, admire and praise her with their gratefulness for "the safe and sound journey". Following the Hoa immigrants, Tian Hou temples were built compatibly in all areas of the Mekong River Delta. After that, they also worship her for the function of protecting, giving happiness and prosperousness, especially protecting newborn babies (Tran, 2005). As a result, there are Tian Hou temples in many districts, towns and cities with many names such as Goddess Temple (天後廟), Tian Hou Palace (天後 宮).

The Mekong River Delta is a sub-area of South Vietnam with the natural characteristics of waterways life-style, wet-rice agriculture and aquaculture as key indutries. This particular ecological economy has led specific impacts on consciousness, philosophy, religion - belief and activities of local residents, in which there is the Hoa community - main followers of the cult of Tian Hou.

South Vietnam is the region that the Hoa gathered most densely (ranking 90\% total of Hoa people in all Vietnam); therefore, it has a greatest number of Tian Hou temples, more than 90 temples. As for the Mekong River Delta, there are over 50 temples, most of them were built from the end of 18th century to early 20th

\footnotetext{
${ }^{4}$ In 1950 the Cantonese was $45 \%$, Chaozhou was 30\%, the Hakka (He) was 10\%, the Fujianese was $8 \%$, the Hainanese took $4 \%$.
} 
century, right on the high tides of the Hoa immigration to Vietnam.

\section{Cultural Characteristics Through the Cult of Tian Hou in the Mekong River Delta}

(1) The Chaozhou of the Ca Mau peninsula has the higher ratio than other places in the Mekong River Delta, also the place that has highest density of Tian Hou temples (Soc Trang-Bac Lieu-Ca Mau). The Hoa in this region often lives in cities and towns, only the minority lives with the Vietnamese and the Khmer in suburbans (for example in Vinh Chau, Nam Can). Meanwhile Tian Hou temples are undiscovered in Long An and Hau Giang provinces, only find out Tian Hou is also praised in Kwan Kong Temple (Vi Thanh city, Hau Giang), Ngu Hanh temple (Long Thuong, Can Giuoc, Long An, ect.).

The cult of Tian Hou in the Mekong River Delta is "polytheism". If the "identical quality" of Cantonese Tian Hou temples in the Southeast is rather high then the popular model of Tian Hou temples in the Mekong River Delta is unfixed, that means diversified. In most of Tian Hou temples, people also worship many gods, such as Kwan Kong, God of Wealth and Fortune (福德正神), Cam Thien Dai De (感天大帝), Ben Tougong) ${ }^{5}$, Kwan Yin, Xi Wang Mu, Mother Dragon Goddess (龍母娘娘), and Jinhua Goddess. Tian Hou temple in Cai Be (Tien Giang) and many other temples also worship at the same time Tian Hou and 2 gods Kwan Kong and God of Wealth and Fortune (fieldwork, 2014). As for the Cantonese Tian Hou Temple in My Xuyen (Soc Trang), the local people worship Tian Hou together with Jinhua Goddess and Mother Dragon Goddess in accordance with the unified style of the Cantonese in Vietnam ${ }^{6}$. Whereas, Tian Hou Temple in Vinh Long city does not worship Mother Dragon Goddess, Cai Rang Temple (Can Tho) worships Tian Hou together with Mother Dragon Goddess and God of Wealth and Fortune. These diversified forms of worship can be originated in many causes including: (1) polytheism from South Chinese (華南地區) has still developed continuously in Vietnam cultural environment; (2) scattered settlement and loose relations beween communities; (3) conception of harmonious yin-yang (worship god-goddess); and (4) all gods or goddess are familiar with the Hoa groups and the Vietnamese, so they can be accepted easily.

In contrast, some temples of Kwan Kong or North Emporer (北帝) also worship Tian Hou. For example in Ong Bac temple (worshipping North Emporer and Kwan Kong temple in Long Xuyen city, An Giang province, Duc De Temple in Vinh Chau (Soc Trang) worship God of Wealth and Fortune and Tian Hou (fieldwork 2014). Other Kwan Kong Temples such as Ninh Kieu (Can Tho), Hiep Thien Cung Temple in Cai Rang (Can Tho), in Long Xuyen (Minh Huong Assembly House), etc. also worship Tian Hou.

The diversity in temple distribution and worship together in Tian Hou temples at the Mekong River Delta (mainly Chaozhou) represents two characteristics dispersity and flexibility.

(2) In religious practices, ritual/religious activities within Tian Hou temples in the Mekong River Delta are uncodified in comparison with the temples in Ho Chi Minh city.

For instance, at Tian Hou Birthday ritual, there is not a fixed and common formula. Most of Tian Hou temples celebrate her birthday on March 22nd and 23rd of lunar calendar. On 22nd day, many regions organize bathing ceremony (沐浴) to cleanse the statues, change new clothes and prepare necessaries for the main ritual

\footnotetext{
${ }^{5}$ Ben Tougong (本頭功), also called Cheng Huang God (城隍神), sometimes God of Wealth and Fortune (福德正神), North Emporewr (北帝) (in Thanh Minh Temple, Vinh Chau, Soc Trang), Châu Đạt Quan (Nhi Phu temple, HCM city), Cam Thien Dai De (感天大帝), or God of Wealth (財神), etc.

${ }^{6}$ As for the management board, this temple is imitated the style of Tue Thanh temple (district 5, HCM city) (fieldwork 2014).
} 
in the next day. As for Cantonese Tian Hou temple in My Xuyen (Soc Trang), they hold bathing ceremony on two days before the formal ceremony (on March 21st). On 23rd, the practitioners carry out parade ceremony by putting her holy statue in a palanquin palankeen and taking it around the streets. Rich people prepare roasted pork, offerings, metal juwelries while the poorer the chicken and fruits to cherish her. In Cai Lay Tian Hou Temple, people offer vegetarian food on March 22nd to feast the mass; on 23rd they offer meats to feast only those who earn a membership (fieldwork). Tian Hou temple in Cho Pho (Cau Ke, Tra Vinh) celebrates Tian Hou birthday on the full-moon day of March $^{7}$ (Dang, 2014, p. 442). Formerly the Hoa's festival contains many rituals, in which Tian Hou parade ceremony during the dragon and unicorn dance used not to be indispensable, however it disappears these days.

In some temples at Ca Mau peninsula, Chaozhou and Cantonese dramas (潮戲,奥戲) or Kun Qu (昆曲) are performed in every even year while the others organize Vietnamese traditional performances (in Vinh Long) or Khmer music arts (in An Hiep Tian Hou temple, Soc Trang). Each 10 years, Cantonese Tian Hou Temple in My Xuyen (Soc Trang) invites Thong Nhat music group from HCM city to perform three days in both Cantonese and Vietnamese languages. In recent years, Ba Tri Tian Hou temple has set up "bong roi" performance (magical arts) which is popular among local goddess temples in South Vietnam, whereas Tian Hou and Kwan Kong Temples in Cai Be town both have organised this kind of performance formerly. Of course these activities have been no longer held these days (fieldwork 2014).

The local Vietnamese attend the festival of Tian Hou under many different purposes. Some come to express their respects and hopes for safe and sound family, some come for good fortune, prosperousness in business. The Hoa and the Vietnamese formerly often "rend Tian Hou's money" on the full moon day of January (the mid-January festival by the Hoa and the Vietnamese) and "pay money back" at the end of the year, which is similar to the belief of Goddess of Treasury in North Vietnam. Nowadays, this custom has been decreased due to the modernization, only in few temples such as Chaozhou Tian Hou temple in My Xuyen Town, Soc Trang has maintained.

(3) On the architectural aspect of the temples, there are two main styles have been classified, including (1) Cantonese-Hainanese-Hakka style; and (2) Chaozhou-Fujianese style. The Mekong River Delta mainly enjoys the second style, whereas the first style is very popular in Ho Chi Minh City ${ }^{8}$. The architecture of Tian Hou temples in the Mekong River Delta contains more freedom, colorful popularity in compare with orthodoxy style of Cantonese temples in Ho Chi Minh city.

In The Mekong River Delta, number of Chaozhou temples is the highest, especially in the south of Mekong River - Ca Mau peninsula. The temples have curved roofs similar to the boat, two gables decorated with “chiwen (螭吻)" motif 9 or carp turning into dragon, sculptures of two dragons struggling for pear or the four supernatural creatures (dragon, unicorn, tortoise and pheonix). The fronted walls usually colorful painted

\footnotetext{
7 Tian Hou palace in Chanh Nghia ward, Binh Duong also changed festival of Tian Hou birthday from 23th of March to the full moon day of January or 26th of January lunar calendar (Dang, 2014, p. 442).

${ }^{8}$ In the first group, the most outstanding is Cantonese temple. The structure "工shape inside and口 shape outside", the roof and walls decorated with gods statues, two dragon struggling for pear, gods of sun and moon, for example Quang Trieu Assembly House located on Vo Van Kiet street (district 1, HCMC), Quang Trieu Assembly House in Nguyen Thi Minh Khai street (district 3, HCMC), Tue Thanh temple in Nguyen Trai (district 5, HCMC), Cantonese Tian Hou temple in My Xuyen, Tian Hou temple in Cai Lay (Tien Giang), etc.

9 The second son of dragon according to the legend Dragon has nine sons, has function of fire control, demon expelling, also called chiwen (螭吻, 鸱吻).
} 
"green dragon on the left side and white tiger on the right side", stories of friendship in the peach garden, the eight fairies crossing sea, etc. but red, green and yellow are decisive colors (according to "Ngu hanh (五行)" theory, they are good colors). The fronted girders besides decorated with stag, deer, pine-tree, crane, familiar supernatural creatures also seen the combination of crab-fish (in most of temples, especially in the south of Hau river-Ca Mau peninsula). The Chaozhou usually do not used Tian Hou temple as asssembly house, but Kwan Kong or North Emporer temple (北帝廟), for example Thanh Minh Temple in Vinh Chau (Soc Trang), Hoa An Temple in Soc Trang city, etc. Tian Hou temples are often called by common name "Tian Hou Gong" (or Tian Hou ancient temple (天後古廟), then added region's name to distinguish for example Cai Be Tian Hou Temple, Ca Mau Tian Hou Temple, etc.

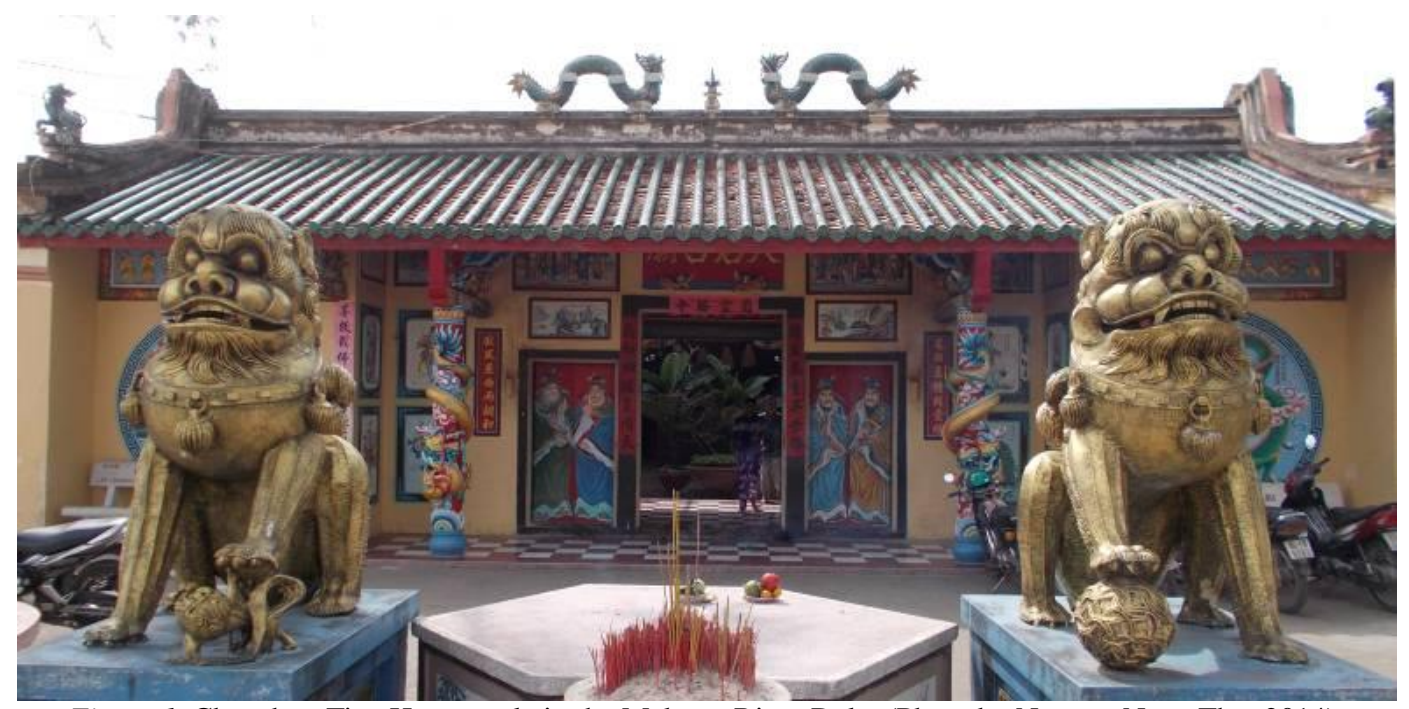

Figure 1. Chaozhou Tian Hou temple in the Mekong River Delta (Photo by Nguyen Ngoc Tho, 2014).

The number of Fujianese in the Mekong River Delta is not high but in each settlement place enjoys a temple (Kwan Kong Temple, Tian Hou Temple, etc.) with curved roofs similar to the boat, two sides of central chamber often had two conical lean-tos looking like Chaozhou's temples but the color is darker. Fujianese temples are distinguished with Chaozhou temples in details such as darker color, fronted walls decorated bas-reliefs of fairies, characters in tales, as well as mural paintings, and small boat models on the roofs (Kien An Temple in Sa Dec, Dong Thap). Most of Fujianese worship gods especially Kwan Kong with the highest rate (for example Kwan Kong temple in Cai Be, Tien Giang), as for Tian Hou goddess, they only worship at the same place with Kwan Kong ${ }^{10}$.

In northern part of Mekong river, due to low number of the Chinese population and low economic potential, so all five groups cooperated to build temples. These temples in general had Cantonese structure (straight roof, bas-reliefs of the four supernatural creatures), but decorated motifs, mural paitings, girders, and gables in accordance with Chaozhou or Fujianese style Tian Hou temples in Cai Be, Cai Lay (Tien Giang), etc. are of this style.

Tian Hou temples are seen as "common house" of Hoa community, therefore they were built with great

\footnotetext{
${ }^{10}$ Fujian people, however the Fujian in Southeast still has some Tian Hou temples for themselves, such as Ha Chuong temple (Nhguyen Trai, district 5, HCMC), On Lang temple (Lao Tu street, district 5, HCMC), Tam Son temple (Luong Nhu Hoc street, district 5, HCMC), Tian Hou temple in Binh Duong (Thu Dau Mot), etc.
} 
size and meticulous decoration. Some of them representing for the two groups usually went together with schools teaching Chinese language and local culture, nowadays some schools have been re-operated such as Vinh Chau Tian Hou Temple (Soc Trang) associated with Boi Thanh Secondary School, Cai Lay Tian Hou temple (Tien Giang) and Cau Tri School ${ }^{11}$, etc.

(4) The cult of Tian Hou together with institution system of worships, rituals and traditional performances of the Hoa culture can be seen as a form of "cultural heritages", that brought to the Mekong River Delta by Chinese immigrants and became fossilzed. An emigrant ethnic minority in a new region always hopes and looks for a system of central symbols with strong power to unite all cultural links and the ethnic consciousness. Tian Hou image is not only a "Goddess" giving prosperousness but also uniting hearts and souls come from the same origin (South China) together to construct the community. The thought of borrowing "the holy" to connect with "earthly" human in the particular context of the South Vietnam has been carried out by the Hoa generations for over 300 years, again proving demands of cultural heritage preservation and development to contribute in the forming of emigrant culture in the new land. Ms. Hua Ngoc Van ${ }^{12}$ confirmed "it's real that the god (North Emporer) and the goddes (Tian Hou) around me, so I feel warm and safe", and "I can not live without visiting her on special occasions..." (field-work interview, 2014). For most of the Chaozhou in Vinh Chau, Tian Hou is a symbol of unification, warming, safety, protection in their profound mind. For that reason, the Hoa has increated vitality of social and spiritual values of this heritage - the cult of Tian Hou.

Discussing emigrant culture of the Hoa and the phenomenon "peripheral fossilization" of South Chinese culture in Southeast Asia, Prof. Kenneth Dean (1956 ) in his paper about "Hictoric changes of the Hoa in the Southeast"13 (2014) emphasized "the continuity" of Chinese traditional worship forms in Southeast Asia, in which the most outstanding belief has been the cult of Mazu-Tian Hou nearly undamaged even if this tradition in China has violently changed towards decreased and faded tendency, especially after Cultural Revolution (1966-1976). In Southeast Asia, worshipping custom simply are spiritual beliefs, usually seen as an important part of the Hoa cultural identity in behavioural correlation with the Southeast Asia. Therefore, in Southeast Asia, the cults are "renovated, changed" towards "non-hierarchy", "non-male chauvinism" then spread back to South Chinese through cultural exchanges between consanguinity communities. It is a fact that in many South China regions, Mother Goddess worship has been damaged, so these "peripheral fossilization" will be very valuable to find back the whole shape of ancient cultural layer.

(5) The cult of Tian Hou in South Vietnam has tendency of "associating/attaching with Buddhism, especially traditional Mahayana Buddhism" (due to its characteristics and functions are close with the cult of Kwan Yin) and Xi Wang Mu of Taoism. Naturally, this phenomenon has originated for a long time, from the period in South Chinese (Liu, 2000). However, in the Mekong River Delta, this trend is more obvious. Tian Hou temple are called "Goddess pagoda", as well as Kwan Kong temple called "God pagoda" as similar as a Buddhist pagoda. South Vietnamese thought that Tian Hou temples are equivalent with "pagodas" or "daoguan (道觀)"; there is no need of distinguishing Tian Hou and Bodhisattva/Kwan Yin in Buddhism ${ }^{14}$ or Xi Wang Mu in Taoism. Kwan Yin/Xi Wang Mu/Yao Chi Jin Mu (瑤池金母) are worshipped in many Tian Hou temples

${ }^{11}$ Now it is a kindergarten.

${ }_{12}$ Born in 1963, Fujian people, the Chaozhou, the owner of Ngoc Van jewelry shop in Vinh Chau, Soc Trang.

${ }_{13}$ Professor of McGill university, Canada, presented in USSH-VNU HCM on March 29, 2014.

${ }^{14}$ The form of worship Tian Hou and Bohisattva/Kwan Yin at the same place is quite popular in the region, for example in Hainanese Tian Hou palace in Kuala Lumpur (Malaysia, fieldwork 2014). 
in the region. Tian hou temple in Cho Pho (Phong Phu, Cau Ke, Tra Vinh) changed festival of Tian Hou's birthday from March 23rd to the full moon day (Phu, 2011), the same time with the local Buddhist festival. In Tian Hou Temple in Cai Rang (Can Tho), people co-worship Kwan Yin by putting Kwan Yin statue in the yard just behind the main gate. As for Cantonese Tian Hou Temple in My Xuyen (Soc Trang), Kwan Yin shrine is built in the yard according to wishes of local people ${ }^{15}$. In Tian Hou Temple in Tra Vinh city, beside for Tian Hou, the left side of the main chamber is place of Kwan Yin shrine (fieldwork 2013). In the local goddess in Thoai Son, An Giang, a local Vietnamese goddess is co-worshipped with Xi Wang Mu under the form of Yao Chi Jin Mu. In return, in some local Buddhist temples, Tian Hou is co-worshipped with Buddha/Kwan Yin, such as Hai Phuoc An Temple in Soc Trang (Tran, 2005).

According to the Hoa's conception, Tian Hou is a sea-goddess, helping their ancestors to overcome miserable ocean reaching the new land safely. From the position as a "sea-goddess", Tian Hou has become a protector for her people with meaningful function of a Bodhisattva or the Xi Wang Mu. However, in Vietnamese and Khmer thoughts, Tian Hou firstly is a "benevolent goddess", a holy "Mother" as other traditional Mother goodesses for example Lieu Hanh, Lady of Realm, etc. With the function as a "Benevolent Goddess, Tian Hou has been accepted basing on Buddhistic view", at least on the form. Many goddess beliefs of Northern Vietnam (Lieu Hanh Goddess, Goddess of Treasury, etc.), South Vietnam (Lady of Realm, Linh Son Thanh Mau, ect.) also share this characteristic. In contrast, in order to present the integration trend into the main flow of Vietnamese culture and attract more visitors, a few Tian Hou temples have set up the statues of Buddha or Kwan Yin to absorb the Buddhist spirit. In the main chamber of Cai Be Tian Hou Temple, all holy statues are arranged pursuant to the order "Bodhisattva/Kwan Yin infront and Tian Hou behind". Tian Hou's birthday on March 23rd has organized under the Buddhist ceremony, the owners invite Buddhist monks to carry out the rituals (fieldwork 2014).

The cult of Tian Hou in South Vietnam is also understood as a symbol of cultural exchanges between the ethnic Hoa, Viet and Khmer, "reflecting the characteristic of multi-ethnic and multi-cultural harmonization" in the Mekong River Delta. In general, the cult of Tian Hou is open, ready for multi-ethnic cultural exchange. It has absorbed Vietnamese and Khmer cultures; moreover, the Vietnamese and the Khmer have also accepted Tian Hou with their respectful hearts.

\section{Conclusion}

The cult of Tian Hou (Mazu) originated in the need of protection from fishermen and businessmen and took part in marine trades in the Southeast of China at the end of Song dynasty. Together with the high waves of South Chinese immigrants to the Southeast Asia, the cult of Tian Hou was spread to the Mekong River Delta from 17th century until the present through many ways by the Hoa migrants directly or indirectly from South China; therefore it has become a popular kind of Mother goddess worship in the Mekong River Delta, existing at the same time with other goddess beliefs in the new land.

With at least 50 temples located in over the delta, in which most of them were built by Chaozhou people, the cult of Tian Hou has enriched the picture of the most particular and lively folk-culture of this region. The cult of Tian Hou in the Mekong River Delta along with its activities such as rituals, performance, social cultural practices and cultural aspects has folklore, flexibility and uncodified characteristics but it became a channel for

\footnotetext{
15 According to the management board, Kwan Yin shrine was built in 1978 due to the need of visiting people (fieldwork 2014).
} 
keeping and spreading traditional culture, as well as an effective and profound education channel for morality and way of life. By the correlation with Vietnamese and Khmer cultures in the region, the cult of Tian Hou has been seen as a special cultural heritage of Hoa community contributing importantly to create particular traits for the cultural idetity of this ethnic.

Thanks on the process of coexistence and integration into Vietnamese society and local culture in the Mekong River Delta, the cult of Tian Hou has changed deeply in its conception as well as ritual practices. Tian Hou has changed her function gradually from a sea goddess proctecting seafarers to a blessing goddess for community, village always giving good fortune, prosperousness and flourishing for people. In general rituals at Tian Hou still maintain the traditional functions harmonized between "the holiness and the earthliness" inherent during the emigration period. It has been continuously supplemented, fixed and received many new elements of delta cultural characteristics through exchange and strong acculturation in the region. That process helps the Hoa enrich their custom and change adapt the new living conditions; therefore, the cult of Tian Hou has gradually developed as a symbol of lively cultural exchange in the Mekong River Delta and over Southern Vietnam.

\section{References}

Cai, X. H. (2006). 臺灣民間信仰專題:媽祖 (Traditional belief in Taiwan: Mazu). 國立空中大學 (Khong Trung University).

Chen, C. H. (1960a). 清初鄭成功殘部之移殖南圻(上) (Trinh Thanh Cong soldiers immigrated to South Vietnam at the beginning of Qing dynasty). 新亞學報 (New Asia Journal), 5(1), 433-459.

Chen, C. H. (1960b). Some comments on Minh Huong town and acient vestige in Hoi An (1/2). Vietnam Archaeology Journal, 1, 15-28. Sai Gon: Ministry of National Education.

Dang, H. L. (2014). Tian Hou festival of Hoa people in the south of Vitenam (the case of Tian Hou palace-Thu Dau Mot, Binh Duong and Tian Hou temple - district 5, Ho Chi Minh city. Mother goddess worship in the south of Vitenam—identity and value. HCMC National University Publishing House.

Fujiwara, R. (1949). 廣南王阮氏と華僑: 特に阮氏の對華僑方針について (Overseas Chinese under Nguyen dynasty in the South of Vietnam: Government policy towards overseas Chinese). 東洋史研究 (Journal Indochina Research), 10(5), 378-393.

Li, L. L. (2003). 妈祖神韵 (Mazu fortune). 学范出版社 (Hoc Pham Publishing House).

Li, X. Z. (1995). 媽祖 (Mazu). 澳門海事博物館 (Macau Ocean Affairs Museum).

Liu, T. S. (2000). The cult of Tian Hou (empress heaven) in Hong Kong. Hong Kong: Joint Publishing Co. Ltd.

Luo, C. R. (2006). 媽祖文化研究 (Researching Mazu culture). 天津古籍出版社 (Co Tich Thien Tan Publishing House).

Ma, S. T., \& Ma, S. X. (2006). 全像媽祖 (Mazu whole statue). 江西美術出版社 (Giang Tay Fine Arts Publishing House).

Mio,Y. (2008). 東南アジアにおける中国系住民の土著化・クレォール化についての人類学的研究 (Sojouring and indigenization of Chinese immigrants: A case study from Hoi An, Vietnam. Anthropology). 東京: 東京外国語大学 (Tokyo University of Foreign Studies).

Nguyen, N. T. (2009). Goddess beliefs in Chinese Ling'nan area. Retrieved from www.harvard-yenching.org

Nguyen, N. T. (2011). Mother goddess belief in Hua Nan. Science and Technology Development Journal, 14, 42-60.

Nguyen, T. L. H. (2014). Integrated element in the cult of Vietnamese Mother goddess at Hoa Duc Tinh Quan temple. In V. Kim, T. Chau, \& T. Giang (Eds.), Mother goddess worship in the south of Vietnam-identity and value (pp. 568-581). HCMC National University Publishing House.

Phan, A. (1990). The Hoa in District 6, Ho Chi Minh city. Vietnamese Fatherland Front of District 6, HCMC.

Phan, A. (2002). Tian Hou worshiping rituals of the Hoa in Ho Chi Minh city. Religious Research Journal, 3, 54-57.

Phu, V. H. (2011). Mother goddess worship in the Mekong River Delta. author's document.

Thinh, N. D. (2001). Belief and belief culture in Vietnam. Social Sciences Publishing House.

Tran, H. L. (2005). The Hoa culture in the south of Vietnam. Social Sciences Publishing House. 
Tran, H. L. (2006). Rituals and traditional festival of Tian Hou in Vietnam in the period of international integration. Paper in Asian Folklore Conferencce, Folklore Culture Institute.

Tsai, M. K. (1968). Les Chinois au Sud Vietnam (The Hoa in the South of Vietnam). Paris: Bibliotheque Nationale.

Wolfram, E. (1968). The local cultures of South and East China, translated from German by Alide Eberhard, Leiden E.J. Brill.

Xu, X. W. (2007). 媽祖信仰史研究 (Researching history of Mazu belief). 海風出版社 (China: Hai Phong Publishing House).

Xu, W. T., \& Xie, Q. Y. (2000). 大南實録清越關係史料彙編 (The collection of Vietnam-related historical facts in Dai Nam Thuc Luc). 台北:中央研究院 (Taipei: Academia Sinica).

Zhu, T. S. (1990). 媽祖信仰應與當前社會相協調 (The cult of Mazu should be harmonized with current society). 廈門大學學 報 (Xia Men University Journal), 4, 86-89. 